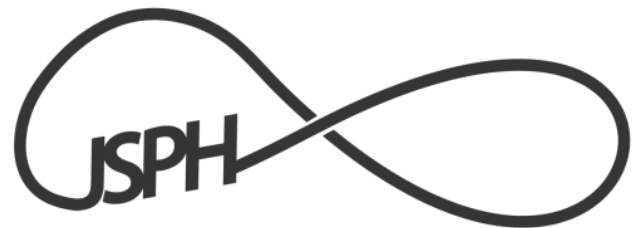

Jurnal Sosiologi Pendidikan Humanis
U

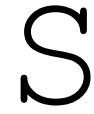

E

$\perp$

Jurnal Sosiologi Pendidikan Humanis

Volume 1, Nomor 1, Maret 2016, Halaman 47-55

ISSN : 2502-7875

\title{
RUANG PUBLIK KATUP PENYELAMAT PENDUDUK LANJUT USIA (STUDI GERONTOLOGI SOSIAL DI PONDOK SEPUH PAYAMAN MAGELANG)
}

\author{
Luhung Achmad Perguna \\ Program Studi Pendidikan Sosiologi Fakultas Ilmu Sosial Universitas Negeri Malang \\ Email: luhung_ap@yahoo.com
}

\begin{abstract}
Abstrak
Penduduk lanjut usia masih sering dianggap beban ketimbang aset terlebih makin masifnya industrialisasi. Industrialisasi menjadikan lansia kelompok rentan dan marginal. Merubah mindset lansia sebagai aset membutuhkan komitmen dan dukungan semua pihak termasuk keluarga dan kerabat lansia. Warga lansia harus disediakan ruang publik deliberatif dalam pembangunan, pelayanan sosial dan mental spiritual dalam menghadapi akhir hidupnya. Ruang publik yang mengakomodir pelayanan sosial untuk terus menghidupkan mental spiritual dibutuhkan lansia, Pondok Sepuh Payaman Magelang salah satunya. Tulisan ini memfokuskan pada kajian tentang gerontologi sosial dalam konteks marginalisasi lansia dalam pusaran industrialisasi sekaligus membahas pelayanan lansia dalam bentuk ruang publik yang ramah bagi mereka. Artikel ini menggunakan pendekatan naturalistik dengan wawancara dan observasi sebagai bagian tak terpisahkan dalam studi ini. Hasil penelitian menunjukkan pondok sepuh menjadi salah satu model ruang publik di Indonesia yang berfokus pada pelayanan sosial keagamaan yang nyaman bagi lansia. Prinsip kebebasan, kesamaan, dan kemerdekaan menjadi hal kunci pada pondok ini. Interaksi dan sosialisasi yang berlangsung didalamnya meningkatkan eksistensi dan kebermanfaatan ditengah marginalisasi kelompok lanjut usia baik di desa maupun kota.
\end{abstract}

Kata Kunci: lanjut usia, industrialisasi, pelayanan sosial, pondok sepuh

\section{PUBLIC SPACE AS A RESCUE VALVE FOR ELDERLY POPULATION(STUDY OF SOCIAL GERONTOLOGY AT PONDOK SEPUH PAYAMAN MAGELANG)}

\begin{abstract}
Industrialization make the elderly people are often considered to be the burden rather than anset. Industrialization makes seniors vulnerable and marginalized groups. Change the mindset of the elderly as an asset requires commitment and support of all parties, including families and elderly relatives. Senior citizens should be provided in a deliberative public space development, social services and mental and spiritual in facing the end of their life. The public space that accommodate social services to continue the mental and spiritual needs of elderly, Pondok Sepuh Payaman Magelang one of them. This paper focuses on the study of social gerontology in the context of the marginalization of the elderly in the vortex of industrialization as well discuss elderly care in the form of a friendly public space for them. This article uses a naturalistic approach with interviews and observations as an integral part in the study. The results showed pondok sepuh into a public space model in Indonesia which focuses on social services for the elderly religious comfortable. Principles of freedom, equality, and freedom becomes the key thing in this cottage. Interaction and socialization that takes place inside the existence and usefulness amid increasing marginalization of the elderly in both rural and urban areas.
\end{abstract}

Keywords: elderly, industrializatiPon, social service, pondok sepuh 


\section{LATAR BELAKANG}

Banyak kalangan menyebut Indonesia saat ini memasuki periode yang dikenal dengan bonus demografi yaitu ketika penduduk usia produktifnya lebih tinggi dibanding usia penduduk lainnya. Puncaknya akan terjadi tahun 2028-2031. Dengan kekuatan tenaga kerja produktif yang besar, Indonesia diharapkan mampu menguasai pasar ekonomi dunia. Konsekuensi logis dari meningkatnya jumlah usia produktif yaitu akan terjadi peningkatan jumah penduduk lanjut usia pada tahun-tahun yang akan datang. Berdasar data Badan Pusat Statistik menyebutkan penduduk lansia terus bertambah dari waktu ke waktu. Pada tahun 2000 terdapat 14 juta jiwa penduduk lansia dengan usia harapan hidup 65 tahun. Saat ini jumlah lansia sudah mendekati angka 30 juta jiwa dengan usia harapan hidup 71,7 tahun. Angka ini diprediksikan akan terus meningkat menjadi 41 juta jiwa di tahun 2035. Bahkan pada tahun 2050 diperkirakan satu dari empat penduduk Indonesia adalah penduduk lanjut usia.

Jumlah penduduk lansia yang terus meningkat ini berpotensi memberikan banyak benefit jika dapat dimanfaatkan sebaik mungkin. Bahkan diprediksi penduduk lansia dengan Usia Harapan Hidup yang makin tinggi tersebut bakal menjadi bonus demografi kedua bagi Indonesia, dengan syarat dibarengi dengan peningkatan kualitas hidup lansia dalam segala bidang. Angka Usia Harapan Hidup (UHH) yang tinggi di Indonesia menunjukkan keberhasilan pembangunan manusia utamanya dibidang kesehatan. Bahkan tren angka UHH Indonesia sedikit lebih tinggi dibanding rata-rata UHH dunia yaitu 71 tahun (UN, World Population Prospect, the 2012 revision). Oleh banyak demograf Indonesia disebut akan mengalami bonus demografi kedua bila kondisi tersebut dapat dimanfaatkan dengan baik, tetapi jika UHH ini tidak dibarengi dengan kualitas warga lanjut usia maka lanjut usia hanya menjadi jalan terjal dalam pembangunan. Tingginya angka UHH di Indonesia ini sedikitnya dikarenakan tiga faktor; (1) kemajuan dalam bidang kesehatan ; (2) meningkatnya sosial dan ekonomi ; (3) meningkatnya penge tahuan masyarakat (Nugroho, 1995). Feno mena peningkatan jumlah lansia di Indonesia dari waktu ke waktu bukan berarti tanpa masalah. Permasalahan makin bertambah dengan mindset masyarakat yang menganggap penduduk lanjut usia hanya menjadi beban bagi keluarga, masyarakat, dan Negara. Beban ini bisa menjadi demographic time bomb(bom waktu demo grafi) ketika keluarga, masyarakat dan negara tidak mempersiapkan penduduk lanjut usia dengan baik. Penduduk lanjut usia dalam masa tuanya akan menghadapi persoalan dari kesehatan, sosial hingga masalah ekonomi. Permasalahan ini disebabkan keterbatasan lanjut usia karena faktor usia dan biologis (Noto-admojo, 2007). Berkenaan dengan hal tersebut, maka kelompok lanjut usia perlu mendapat perhatian serius dari semua pihak khusus nya pemerintah melalui ragam program dan kebijakan yang pro terhadap kelompok lansia sehingga pada gilirannya mereka dapat berpartisipasi dalam pembangunan nasional dan tidak menjadi beban bagi keluarga, masyarakat dan negara. Kebijakan dan program pro lansia dinilai urgen mengingat mereka juga warga negara yang harus dilindungi dan diayomi oleh negara bukan malah sebaliknya yang sering dijadikan objek pembangunan. Dalam pasal 5 UU No.13 tahun 2008 disebutkan bahwa hak pemenuhan lansia meliputi: (1) pelayanan keagamaan dan mental spiritual; (2) 
pelayanan kesehatan; (3) pelayanan kesempatan kerja; (4) pelayanan pendidikan dan pelatihan; (5) kemudahan dalam mengguna kan fasilitas,sarana dan prasarana umum;(6) kemudahan dalam layanan bantuan hukum; (7) perlindungan sosial, dan (8) ban tuan sosial. Kedelapan hal dalam UU ter sebut menjadi penting dan saling terkait terkhusus bagi kelompok lansia. Tanpa mene gasikan keterkaitan antara satu dan lainnya, penulis fokus pada pelayanan keagamaan dan mental spiritual dalam kaitannya dengan ruang publik yang ramah bagi lansia dan interaksi yang terjadi di dalamnya dalam meningkatkan usia harapan hidup lansia. Salah satu ruang publik tersebut yang di khususkan bagi lansia terdapat di Payaman Magelang dengan model Pondok Sepuh.

\section{METODOLOGI}

Kajian tentang gerontologi sosial kaitannya dengan pelayanan keagamaan dan mental spiritual dalam tulisan ini lebih menitikberatkan pada kelompok lansia muslim yang mana mayoritas penduduk Indonesia beragama Islam. Studi gerontologi ini sudah banyak dibahas oleh para ahli meski dominasi perspektif kedokteran dan ekonomi lebih menonjol dibanding studi lainnya. Kemudahan aksesibilitas informasi terhadap kajian ini baik melalui media luring atau pun daring dapat diamati secara kualitatif dengan pendekatan eksploratif dan bisa dijadikan sebagai bagian dari sumber data penelitian. Studi lapangan yang berfokus pada ruang publik khusus lansia (pelayanan keagamaan dan mental spiritual) yaitu Pondok Sepuh yang berada di kecamatan Payaman kabupaten Magelang dengan menggunakan pendekatan naturalistik dengan jaringan keluarga (kinship) juga dilakukan dalam penelitian ini untuk mengamati ruang publik (pelayanan keagamaan dan mental spiritual). Model purposive dipilih untuk dapat mengetahui pondok sepuh secara utuh. Wawancara dengan informan (dengan menggunakan bahasa Jawa krama alus) dan observasi partisipan dilakukan dalam penelitian ini sebagai bagian dalam mengumpulkan informasi sedalam mungkin. Kelak kajian dan khazanah keilmuan ini dapat menjadi model pelayanan keagamaan dan bisa menjadi bagian menarik dan penting bagi studi sosiologi yang terkait dengan demografi sosial dan gerontologi sosial.

\section{HASIL DAN PEMBAHASAN \\ Lansia dalam Pusaran Industrialisasi}

Menjadi tua adalah bagian dari suatu proses biologis yang dialami oleh setiap manusia. Tak pandang bulu dengan status sosial, ekonomi, jabatan dan seberapa hebat dan kuatnya seseorang akan melewati satu fase dimana rambut mulai memutih, kerutan demi kerutan di wajah kian bertam-bah, gerakan yang semakin lamban, menurunnya fungsi otak seperti sering lupa atau bahkan pikun dan penyakit-penyakit yang mulai menjangkiti warga lanjut usia. Interaksi sosial lansia juga cenderung menurun disebabkan kerusakan kognitif, kematian keluarga, fasilitas hidup dan juga home care (Estelle, Krisck \& Pollack, 2006). Gambaran ini merupakan gambaran umum yang terjadi pada setiap lansia. Warga lansia yang mengalami penurunan derajat kesehatan dan kemampun fisik makin diperparah dengan minimnya jumlah pelayanan sosial dan kesehatan yang memadai (Fitria, 2011). Dalam kondisi yang demikian, kelompok lansia ini sangat membutuhkan dukungan dan bantuan dari pihak lain terutama keluarganya yaitu anak dan cucucucunya.Kekerabatan menjadi salah satu 
penyelamat lansia dari kerentanan (Kagitcibasi \& Ataca 2015). Sayangnya, anak-anak dan kerabat yang diharapkan menjadi katup penyelamat tidak cukup waktu dan perhatian yang diberikan oleh mereka kepada lansia. Sebagai akibatnya, para orang tua sering merasa frustasi dalam menjalani masa kehidupan usia emas mereka (Nangombe \& Ackermann 2012).

Marginaliasi penduduk lanjut usia diperparah dengan proses industrialisasi yang mengakibatkan perubahan sosial ekonomi (Bahruddin, 2012). Perubahan ini tidak hanya perubahan pada mata pencaharian nuclear family (keluarga inti) tetapi juga perubahan nilai-nilai yang dianut selama ini. Perubahan masyarakat agraris ke masyarakat industri juga membawa implikasi kepada peran-peran lansia yang hilang atau terganti. Industrialisasi memberi pengaruh pada pergeseran aktivitas ekonomi dari desa menuju kota. Kota menjadi pusat aktivitas ekonomi mengakibatkan banyak penduduk desa produktif berpindah ke kota, urbanisasi menjadi jalannya. Mudahnya mendapat uang di kota menjadi ketertarikan bagi tenaga produktif desa untuk pindah ke kota. Anak dan keluarga yang diharapkan memberi dukungan sosial secara langsung kepada lanjut usia terutama yang tinggal di desa justru tidak dapat memberikan dukungan dan pelayanan kepada lansia dikarenakan harus bekerja atau melakukan aktivitas lainnya yang jauh dari orang tua sehingga jarang ditemui extended family (keluarga tambahan) dalam arti memiliki dua kepala keluarga dalam satu rumah. Dengan kecenderungan seperti itu, rasio gini makin melebar dan kota, akibatnya makin memarginalisasi warga lansia. Terlebih berdasar Badan Pusat Statistik 60 persen masyarakat lansia berada di pedesaan yang berarti kondisi lansia makin rentan dan memprihatinkan.

Akibat industrialisasi pula partisipasi kerja tenaga usia produktif meningkat baik itu laki-laki maupun perempuan. Pada satu sisi hal itu akan meningkatkan keuangan keluarga dan mendukung kehidupan perekonomian, di sisi yang lain menghambat tenaga kerja usia produktif itu merawat orang tua yang sudah lanjut usia. Industrialisasi dan partisipasi kerja khususnya usia produktif membuat penduduk lanjut usia berada pada posisi yang rawan. Rawan karena mereka perlahan kehilangan sumber ekonomi dan sumber daya yang dapat merawat pada usia tuanya. Interaksi sosial lanjut usia dengan teman sebaya menjadi sebuah hal yang wajib bila mereka tidak ingin rawan pada usia lanjutnya.

Kebutuhan untuk berinteraksi sosial dengan orang lain akan dimiliki individu hingga kematian menjemput. Masyarakat lanjut usia membutuhkan interaksi dengan masyarakat publik lainnya karena pada dasarnya manusia adalah makhluk homo socius terlebih bagi kelompok lansia (Thanakwang, 2011) Ruang publik khusus bagi masyarakat lanjut usia seharusnya hadir untuk menjawab kebutuhan lanjut usia dalam berinteraksi baik dengan kelom-pok usianya ataupun lainnya. Sayangnya, masih sangat sedikit ditemukan ruang publik terhadap penduduk lanjut usia. Padahal penduduk lanjut usia merupakan bagian penduduk dari kota yang memiliki hak yang sama dalam pemanfaatan dan penggunaan ruang publik.

\section{Ruang Publik wujud Eksistensi}

Ada ragam ruang publik yang tersebar di Indonesia. Keragaman itu memunculkan tafsir dan persepsi atasnya yang berbeda pula. Karena maknanya yang cukup bera- 
gam tersebut, istilah ruang publik digunakan secara bebas dalam ragam kajian yang berbeda-beda. Dalam perspektif arsitektur misalnya, makna ruang secara sederhana disamakan dengan wadah, yakni tempat berlangsungnya kegiatan, yaitu segenap aktivitas manusia yang tidak pernah lepas dari keberadaan ruang sebagai wadah kegiatannya (Lefebvre, 2004). Ruang publik sendiri merupakan wadah yang mempunyai kualitas kepublikan sejauh dapat menam pung berbagai entitas dengan ragam kepen tingannya (Wibowo (ed), 2005). Sedang dalam perspektif Habermas ruang publik dipahami dengan konkret - empiris yaitu berupa sebuah ruang tertentu yang memiliki batas-batas dan aturan main tersendiri, misalnya klub, warung kopi, sa-lon, table societies dan lain-lain (Haber-mas,1989).

Fakta di Indonesia penyediaan ruang publik masih sangat kurang terlebih yang diperuntukkan bagi lansia. Bahkan bila ruang publik diidentikan sebagai sebuah taman yang ramah bagi lansia, maka hanya ada satu taman di Indonesia yang menggunakan nama "Lansia" meski perlu ditelisik lebih dalam tingkat keramahan dan kenyamanan bagi lansia di taman lansia di kota Bandung tersebut. Sedang dalam pelayanan kesehatan khusus lansia, proporsi jumlah pelayanan kesehatan antar satu propinsi dengan propinsi lainnya berbeda. Paling tidak dari seluruh propinsi yang ada di Indonesia, terdapat 15 propinsi masih belum tersedia pelayanan kesehatan khusus lansia. Propinsi yang paling banyak memiliki pusat kesehatan lansia atau dikenal dengan istilah posyandu lansia adalah propinsi Jawa Timur yang mencapai 52 ribu lebih (Kemenkes,2013). Menurut hasil observasi penulis di Kabupaten Blitar pada November 2015 tepatnya di kecamatan Garum misalnya, posyandu lansia ini an sich tidak hanya menitikberatkan pada persoalan kesehatan baik dengan upaya preventif maupun promotif. Namun juga memberikan pelayanan pada persoalan sosial, agama, pendidikan, keterampilan, seni, olahraga dan pelayanan lainnya yang dibutuhkan para lansia untuk meningkatkan kualitas kehidupan melalui peningkatan kesejahteraan dan kesehatan. Selain itu diharapkan posyandu lansia ini dapat memacu lansia agar dapat beraktivitas sebagai seorang warga Negara yang dihormati, juga sekaligus dapat mengembang-kan potensi diri. Posyandu lansia ini diharapkan menjadi role model pelayanan kepada lansia dan salah satu bentuk ruang publik yang menarik bagi lansia.

Selain posyandu lansia, ada satu ruang publik terdapat satu ruang publik yang berada di Payaman Magelang yang khusus diperuntukan bagi lansia baik laki-laki maupun perempuan. Masyarakat sekitar menyebutnya dengan "Pondok Sepuh". Nama itulah yang disepakati bersama menjadi sebuah tempat tinggal yang ramah bagi masyarakat lanjut usia. Disebut Pondok karena ditempat ini para lansia bisa tinggal disana layaknya sebuah rumahmeski minim fasilitas yang memadai dalam jangka waktu yang tidak ditentukan bahkan dengan biaya yang sangat murah. Selain itu pondok identik dengan tempat yang di peruntukkan untuk seseorang yang tinggal dalam jangka waktu tertentu dengan suatu keyakinan /agama yang sama. Sedang di katakan sepuh (dari bahasa Jawa yang ber arti tua) karena tempat ini hanya diperun tukkan untuk masyarakat lanjut usia yang ingin memperdalam ilmu agama dan men cari bekal pada kehidupan setelah kehi dupan di dunia. 
Pondok Sepuh bisa dikatakan sebagai ruang publik bagi masyarakat lanjut usia. Tempat ini merupakan ruang komunal milik bersama khususnya masyarakat lanjut usia yang melakukan aktivitas secara fungsional baik secara individual maupun dalam kelompok aktivitas. Pondok ini terus mengalami peningkatan dari tahun ke tahun baik dari sisi bangunan maupun jumlah penduduk lanjut usia yang ingin belajar dan akhirnya tinggal disana. Bahkan bila Ramadhan tiba, pondok ini penuh sesak dengan jumlah warga lanjut usia yang tinggal mencapai 500 orang dengan didominasi oleh wanita. Mereka para lansia melakukan aktivitasnya dalam satu tempat secara bersama dengan satu tujuan yaitu beribadah dan mendekatkan diri pada Allah. Pondok ini menjadi media interaksi antar penduduk lanjut usia, sehingga makin mereka melakukan interaksi makin eksistensi mereka diakui. Interaksi yang terus terbangun ini pada akhirnya mengakibatkan munculnya semangat untuk terus hidup dengan diisi amalan-amalan agama. Berdasar perspektif ruang publik maka pondok sepuh adalah sebuah wadah yang didalamnya terdapat ragam entitas dengan memiliki batas-batas dan aturan main tersendiri. Entitas yang ditampung bisa berupa kelompok baik modern maupun tradisional dengan berbagai ideologi termasuk kepentingan yang menyertainya.

Aktivitas sosial warga lansia yang tinggal di pondok sepuh penuh ragam dan warna. Pengasuh pondok sepuh yang juga warga sekitar dan pengelola Masjid Agung Payaman Magelang berupaya untuk memandu jalannya ragam kegiatan pondok. Meski ada kiai, namun sosok kiai tidak begitu berperan sentral sebagaimana pondok salafiyah yang diperuntukan untuk anak atau remaja. Kajian dengan model bandongan, sorogan, nderes dan berbagai kegiatan lainnya terus dilakukan di pondok sepuh selama lebih dari 12 jam dalam satu hari. Aktivitas yang ada di pondok inisangat beragam dan penuh warna. Pola aktivitas seakan sudah terbentuk di antara warga lansia di pondok sepuh. Baik itu aktivitas yang sifatnya sebuah proses, kontak fisik ataupun sekadar aktivitas transisi di dalam sebuah ruang publik (Zhang and Lawson, 2009).

Didalam pondok sepuh tidak ada jadwal ketat yang mengatur para lansia untuk mengikuti aturan main yang ada. Bahkan tidak ada paksaan pula apakah warga lansia tersebut harus tinggal untuk jangka waktu yang lama, untuk Berdasar observasi penulis, geliat kehidupan komunitas lansia dimulai pada pukul 01.30 dini hari dengan melakukan sholat tahajud dan ritual ibadah lainnya seperti membaca Al Quran atau sekadar wiridan. Aktivitas spiritual terus mereka lakukan meski juga diselingi aktivitas lainnya seperti aktivitas proses, kontak fisik dan juga aktivitas transisi selama 24 jam. Bila menilik teori aktivitas (Nugroho, 2000) maka dengan terus melakukan aktivitas di antara mereka dan juga dengan warga lainnya maka keadaan sosio-psikologis dan kesejahteraan lansia akan terus eksis. Teori aktivitas ini mengafirmasi hubungan positif antara mempertahankan interaksi yang penuh arti terhadap orang lain dengan kesejahteraan fisik dan mental lansia. Aktivitas sosial komunitas lansia ini sendiri baru berakhir pada pukul 08.00 malam.

Kegiatan pondok sepuh meski terdapat kegiatan yang padat, tetapi tidak ada aturan tertulis yang mengikat untuk mengikuti atau tidak mengikuti kegiatan yang ada. Tidak ada paksaan apakah penghuni pondok sepuh harus tinggal menetap lama, sebentar 
atau bahkan hanya beberapa hari. Bila dibandingkan dengan pondok yang menyelanggarakan kegiatan formal, pondok ini jelas berbeda. Tidak ada ujian. Tidak ada laporan hasil prestasi yang diberikan sebagaimana lazimnya lembaga pendidikan formal. Prestasi tertinggi bagi penghuni pondok sepuh adalah meninggal dalam keadaan yang baik (husnul khotimah) dengan diisi kegiatan yang mendekatkan kepada Sang Pencipta. Pelajaran, jadwal dan kegiatan formal sebagaimana lembaga formal juga tidak ada. Tidak ada pula aturan ketat untuk tetap tinggal di pondok. Bagi mereka yang betah bisa tinggal selama mungkin, bagi yang tidak betah mereka pun bisa pulang seenaknya. Mereka diberikan kebebasan untuk menjalin interaksi antar penghuni pondok satu dengan lainnya atau penghuni pondok dengan warga sekitar pondok. Penghuni pondok sepuh hanya dibebankan biaya Rp.17.000,- dalam satu bulan sebagai pengganti air, kebersihan dan juga listrik yang mereka telah gunakan. Meski hanya membayar uang pengganti yang tidak mahal, fasilitas yang disediakan di Pondok Sepuh seperti kamar mandi, tempat wudhu atau bahkan kamar terbilang cukup baik meski tidak bisa dikatakan mewah. Dalam kesehariannya mereka makan dengan memasak sendiri atau membeli sayur yang ada di sekitar masjid agung Payaman yang harganya sangat terjangkau dan mudah diperoleh (Perguna, 2015).

Selain pola aktivitas yang sudah terbangun, di pondok sepuh terdapat keragaman aktor sosial yang berasal dari berbagai lapisan sosial ekonomi. Sebagian besar warga di pondok sepuh didominasi oleh kaum wanita dengan mencapai 63 dari total 80 penghuni pondok sepuh yang berarti terdapat kesenjangan gender disana.
Hal ini dapat dimengerti, karena masih kentalnya budaya patriarki di tanah Jawa. Dalam makna yang lebih luas apabila orang tua lanjut usia laki-laki ditinggal mati oleh pasangannya maka dia akan dengan mudah untuk menikah. Namun sebaliknya, bila pasangan yang meninggal adalah suami/ laki-laki maka kecenderungan wanita lanjut usia untuk menikah jauh lebih kecil sehingga berdampak pada interaksi wanita lanjut usia yang berkurang pasca ditinggal pasangannya. Akhirnya pilihan rasional wanita lanjut usia memilih pondok sepuh sebagai means/ sarana dalam mencapai tujuan yang hendak dicapai sambil menghabiskan sisa umur yang tak lama lagi. Di Pondok Sepuh ini pula lebih dari 90 persen penghuni berasal dari tanah Jawa, sehingga ada homogenitas kultur di dalamnya. Bahasa Jawa kromo alus menjadi bahasa sehari-hari dan merupakan wujud kesadaran kolektif orang Jawa untuk merefleksikan rasionalitas masyarakat terutama di Pondok Sepuh.

Yang menarik juga selain aktivitas sosial dengan balutan ritual keagamaan, di dalam pondok sepuh juga terdapat aktivitas politik, ekonomi dan pasar seperti ditegaskan Habermas (2007:112) bahwa ruang publik selalu berkaitan dengan aktivitas politik, ekonomi dan pasar.

\section{PENUTUP}

Fenomena transisi demografi, salah satunya ditandai dengan meningkatnya populasi jumlah lansia yang terus mening kat. Fenomena ini tentu akan menjadi bom waktu demografi bila tidak ditangani dengan baik oleh pemerintah dan juga masyarakat. Warga lansia masih dianggap sebagai beban dan bukan aset. Lansia makin rentan posisinya karena seringkali tidak dianggap dan tidak dilibatkan dalam kebijakan, bahkan dikucilkan di tengah 
masyarakat karena dianggap tak berdaya lagi. Proses industrialisasi masyarakat makin memperburuk kondisi lansia. Lansia membutuhkan ruang publik yang ramah bagi mereka untuk berinteraksi, ber sosialisasi satu sama lain karena pada dasarnya manusia adalah homo socius. Salah satu bentuk ruang publik yang menarik dan telah lama berdiri dan diuji oleh waktu khusus untuk lansia adalah Pondok Sepuh. Pondok ini menjadi tempat entitas saling berinte-raksi untuk me nunjukan eksitensi mereka. Prinsip ke mandirian, kesetaran dan kebe-basan dibalut dalam suasana yang religius dalam ritual keagamaan berlangsung di pondok ini se hingga makin membuat pondok ini menjadi eksis. Ruang publik ini seakan menjadi oase sekaligus katup penyelamat bagi warga lanjut usia di tengah program dan kebijakan pemerintah yang sering memandang sebelah mata warga lansia.

\section{DAFTAR PUSTAKA}

Bahruddin (2010). Pengarusutamaan Lansia dalam Pelayanan Sosial. Jurnal Sosial Politik Vol 13 No.3. 275 - 290.

Estelle JJ, Kirsch NL \& Pollack ME.(2006) Enhacing Social Interaction in Elderly Communities. CM Conference on Human Factors in Computing System.CHI

Fitria, A. (2011). Interaksi Sosial dan Kualitas Hidup Lansia di Panti Wredha UPT Pelayanan Sosial Lanjut Usia dan Anak Balita Wilayah Binjai dan Medan.Medan.USU.

Habermas, Jurgen. (1989). The Structural Transformation of Public Sphere: An Inquiry into Category of Bourgeois Society, Thomas Burger (terj.). Cambridge: Polity Press.
Habermas, Jurgen .(2007). Ruang Publik:

Sebuah Kajian tentang Kategori Masyarakat Borjuis. Yogyakarta. Kreasi Wacana.

Kagitcibasi, Cigdem and Ataca, Bilge. (2015). Value of Children, Family Change and Implications for the change of Elderly. Cross-Cultural Research, 49, 374-392.

Levebfre, Henri. (2004). Rhythmanalysis, Space Time and Everyday life. London. Continuum.

Nangombe, Hilma and Ackermann, Leane. (2013). Subsistence and Protection Need of The Elderly Living in Katutura (Namibia). Research on Aging, vol. 35 no. 2 182-200

Nugroho, Wahyudi. (1995). Perawatan Lanjut Usia. Jakarta. EGC.

Nugroho, Wahyudi .(2000). Keperawatan Gerontik Edisi 2.Jakarta. EGC

Notoadmojo.(2007). Kesehatan Masyarakat Ilmu dan Seni. Jakarta. PT.Rineka Cipta.

Thanakwang, Katika and Soonthorada. (2011). Mechanism by Which Social Support Network Influence Healthy Aging Among Thai Community Dwelling Elderly. Journal of Aging and Health, 1-27.

Perguna, Luhung Achmad.(2015). Pondok Sepuh: Public Space for Elderly. Proceeding 7th International Graduate Students and School Conference in Indonesia. Yogyakarta.

Wibowo, Sunaryo Hadi (ed).(2005). Republik Tanpa Ruang Publik. Yogyakarta: Ire Press.

Zhang and Lawson. (2009). Meeting and greeting: Activities in public outdoor spaces outside high density urban residential communities. Urban Design 
International. Volume 14, 4 (207 - 214).

BPS RI tahun (2014)

UN Nations (2012). World Population

Prospect.

UU Republik Indonesia Nomor 13 tahun 2008. 